be the main reason why measles immunization given by intradermal jet injection is so uncertain. It should also be borne in mind that the vaccines were of different manufacture. The effect of nutritional status on antibody response was checked by examination of the infants' weight charts. Most of the children received at least their first two doses of vaccine before the age of weaning and therefore before the period of "weight faltering" and early malnutrition. Of the 109 children in group 1 from whom the third blood sample was obtained, 50 were below $80 \%$ and four below $60 \%$ of the expected weight for age on one or more visits (usually the last one or two). There was no significant diminution of antibody response in these children.

Immediate reactions to the intradermal injections could not be documented, but few were reported at the next visit. One of us (K.M.W.) has adopted this technique of immunization as a standard procedure with adsorbed D.T.P. and has never had any severe untoward effects reported to him. Small indurated marks about 5-7 $\mathrm{mm}$ in diameter were observed one month after each dose but had disappeared entirely in three to four months. In one underweight child an ulcer about $15 \mathrm{~mm}$ in diameter developed at the site of one of the injections one month later. Unfortunately, no record was made of this and the type of vaccine used is therefore not known. The lesion had healed by the next visit.

\section{Discussion}

These results are encouraging. They indicate that intradermal D.T.P. in reduced dosage can stimulate antibody production to levels similar to those obtained with the standard intramuscular schedule when three doses are given. The use of the intradermal injector enables a very rapid rate of immunization to be maintained, the necessity of sterilizing needles and syringes during the clinic being eliminated. The method is therefore very useful in the field, where a presterilized instrument can be filled with vaccine sufficient for 20 children. The reservoir can be refilled with one syringe and needle as necessary.

General reactions to the intradermal injection of D.T.P. may be less frequent than those after intramuscular injection, as is the case with T.A.B. It would seem likely that the plain vaccine is less reactive locally than the alum-adsorbed vaccine, which has the additional disadvantage of a tendency to froth. To date, hepatitis has not been found to be associated with the use of jet injectors. Although occasionally a spot of blood was noticed on the rim of the nozzle of the instrument, the jet of vaccine does not touch this rim.

The importance of the good results obtained with this method must be judged against the background of large numbers of unimmunized children attending a clinic staffed by a single doctor with few, mostly unskilled, locally trained assistants and meagre facilities. The method is now in use in one or two clinics in Uganda, but further monitoring of the safety and reliability of the technique is still required. It might well be the method of choice for routine immunization clinics in any part of the world.

We would like to thank the Chief Medical Officer, Ministry of Health, Uganda, for permission to publish this material. One of us (P.M.B.) was in receipt of a grant from the Wellcome Trust for the study of modifications of immunization schedules applicable to developing countries. We acknowledge with thanks the generosity of the Wellcome Trust and the encouragement of Dr. J. A. Dudgeon and Professor G. Dick.

The assistance of the staff of Kagando Hospital was willingly and cheerfully given and the close liaison developed during the conduct of the trial between ourselves and the hospital was relinquished most reluctantly.

\section{References}

Dick, G. (1966). Canadian Public Health fournal, 57, 435.

Glenny, A. T., and Llewellyn-Jones, M. (1931). Fournal of Pathology and Bacteriology, 34, 143.

Glenny, A. T., and Stevens, M. F. (1938). Fournal of the Royal Army Medical

Haire, M., Dane, D. S., Dick, G., Briggs, E. M., and Connor, T. J. (1966) fournal of Hygiene, 64, 485 .

Heyworth, B. (1970). Fournal of Tropical Pediatrics and African Child Health, 16,17 .

Ministry of Health (1967). U.K. Circular letter on Immunizations in Childhood, Chief Medical Officer, CMO/20/67.

Moffat, M., and Cook, R. (1970). Report on the Ankole BCG Dermojet Trial mimeo. Department of Paediatrics, P.O. Box 7072, Kampala, Uganda

Rey, M., and Triau, R. (1967). Bulletin de la Société Médicale d'Afrique Noire de Langue Francaise, 12, 230.

Römer, P. H., and Sames, T. (1909). Zeitschrift für Immunitätsforschung und experimentelle Therapie, 3,344

Stanfield, J. P., and Bracken, P. M. (1971). Transactions of the Royal Society of Tropical Medicine and Hygiene, 65, 620.

\title{
Excretion of Urinary Casts after the Administration of Diuretics
}

\author{
P. R. IMHOF, J. HUSHAK, \\ G. SCHUMANN, \\ P. DUKOR, J. WAGNER, \\ H. M. KELLER
}

British Medical fournal, 1972, 2, 199-202

\section{Summary}

The administration of ethacrynic acid and frusemide to healthy volunteers was regularly followed by the excretion of hyaline casts, without any concomitant proteinuria. Hydrochlorothiazide and chlorthalidone did not themselves induce cylindruria but augmented that provoked by acidifying agents. It was shown by the

\footnotetext{
Biological Research Laboratories of the Pharmaceuticals Division of Ciba-Geigy Limited, Basle, Switzerland

P. R. IMHOF, M.D., Head, Human Pharmacology Laboratories

J. HUSHAK, M.D., Clinical Associate, Human Pharmacology Laboratories G. SCHUMANN, PH.D., Senior Biologist, Immunology Laboratories P. DUKOR, M.D., Head, Immunology Laboratories

J. WAGNER, PH.D., Assistant Professor, Senior Chemist, Biochemical Pharmacology

District Hospital, Belp, Switzerland

H. M. KELLER, M.D., Assistant Professor, Physician-in-Chief
}

indirect immunofluorescence method that the casts were composed of uromucoid (Tamm-Horsfall mucoprotein), which is always present in the urine, usually in solution, and originates predominantly from the tubule cells of the ascending limb of Henle's loop. The urinary excretion of Tamm-Horsfall mucoprotein was not increased after the administration of ethacrynic acid. This mucoprotein is precipitated and forms aggregates when the concentration of electrolytes increases and when the pH of the urine declines. The casts that appear in the urine after strenuous physical exertion are of essentially the same composition. Casts produced by patients with kidney diseases, on the other hand, contain various protein fractions derived from the blood as well as mucoprotein. Cylindruria occurring during diuretic therapy and physical exertion is of no pathological significance, and the diagnostic value of byaline casts is very much limited if their exact composition cannot be determined. 


\section{Introduction}

It is still widely believed that the excretion of hyaline casts in appreciable numbers in the urine is an infallible sign of kidney damage. Evidence has, however, now come to light that calls for a thorough revision of this view. We have found casts that certainly cannot be ascribed to any form of renal damage in the urine of persons treated with well-established diuretics.

In the course of pharmacological studies in previously untreated healthy subjects, we discovered quite by chance that the administration of potent diuretics like ethacrynic acid and frusemide is regularly followed by the excretion of hyaline casts. We have attempted to find the explanation for this phenomenon.

\section{Subjects and Methods}

The experiments were carried out on 46 healthy volunteers. In a total of 41 acute tests, single oral doses of $50-100 \mathrm{mg}$ of ethacrynic acid (24 subjects) and $80-160 \mathrm{mg}$ of frusemide (17 subjects) were administered. Six subjects were given ethacrynic acid in a daily dose of $100 \mathrm{mg}$ for five consecutive days, and a further eight $80 \mathrm{mg}$ of frusemide daily for five to eight days. For comparison, the effects of single oral doses of $100 \mathrm{mg}$ of chlorothiazide and $200 \mathrm{mg}$ of chlorthalidone were tested in five subjects each. In addition, water diuresis was induced in four subjects by giving them 2 litres of tea within one hour and osmotic diuresis in six subjects by intravenous infusion of mannitol (500 ml of a $20 \%$ solution over $20-30$ minutes). The drugs were taken at 8 a.m., some of the subjects having fasted for the previous 12 hours. Thereafter, urine was collected at intervals of one or two hours; the volume of each portion was measured, a sample was tested for protein with Labstix or $20 \%$ sulphosalicylic acid, and the sediment was examined microscopically.

Since hyaline casts have a similar refractive index to urine, they easily escape detection, unless they are viewed under a very dimly illuminated microscope, or a phase-contrast microscope. The quantitative estimation of the number of casts present was made by a slightly modified version of the Addis count. To assess the influence of the $\mathrm{pH}$ of the urine on the cylindruria induced by frusemide, three subjects in one test were acidified for two days with ammonium chloride in a dose of $6 \mathrm{~g}$ daily, and three in another test were pretreated for one day with $12 \mathrm{~g}$ of sodium bicarbonate. Before the administration of hydrochlorothiazide and chlorthalidone two subjects in each group were similarly acidified with ammonium chloride. The qualitative composition of the casts was studied by an indirect fluorescence method (Sandwich technique) (Rutecki et al., 1971), with the aid of antisera produced by BehringWerke AG (rabbit antihuman uromucoid, -fibrinogen, -albumin, $-\beta_{1} \mathrm{c} / \beta_{1 \mathrm{~A}}$-globulin, -IgG-globulin, -IgM-globulin, and fluorescein-conjugated goat antirabbit $\gamma$-globulin); the microscope used was a Leitz orthoplane transilluminated fluorescence microscope with a 3-mm BG 12 excitation filter and a K 530 suppression filter.

For purposes of comparison, immunofluorescence tests were also made with urine collected from seven football players just after a strenuous match* and from nine patients with various kidney diseases (chronic glomerulonephritis, pyelonephritis, etc.). In four subjects the concentration of TammHorsfall mucoprotein in the urine was estimated quantitatively by the method of McKenzie et al. (1964) after oral medication with ethacrynic acid in a dose of $100 \mathrm{mg}$. To compensate for the diluent effect of the diuretic the urine first had to be concentrated if the volume excreted exceeded $50 \mathrm{ml}$ per hour. The portion in question was lyophilized and the residue dissolved in distilled water and made up to $50 \mathrm{ml}$.

We are indebted to Dr. H. Zehntner of Basle for kindly supplying us with this urine.

\section{Results}

Morphology of Casts, Proteinuria.-Both ethacrynic acid and frusemide consistently gave rise to the excretion of casts in the urine, often in considerable numbers (Fig. 1). These were invariably hyaline cylinders, occasionally containing fine granules and differing morphologically from case to case, even in subjects given the same drug; they varied in shape from short and stubby to long and slender, some of them having thin, elongated, and convoluted "tails." Many were distinctly spiral in form (Fig. 2). From a purely morphological point of view there

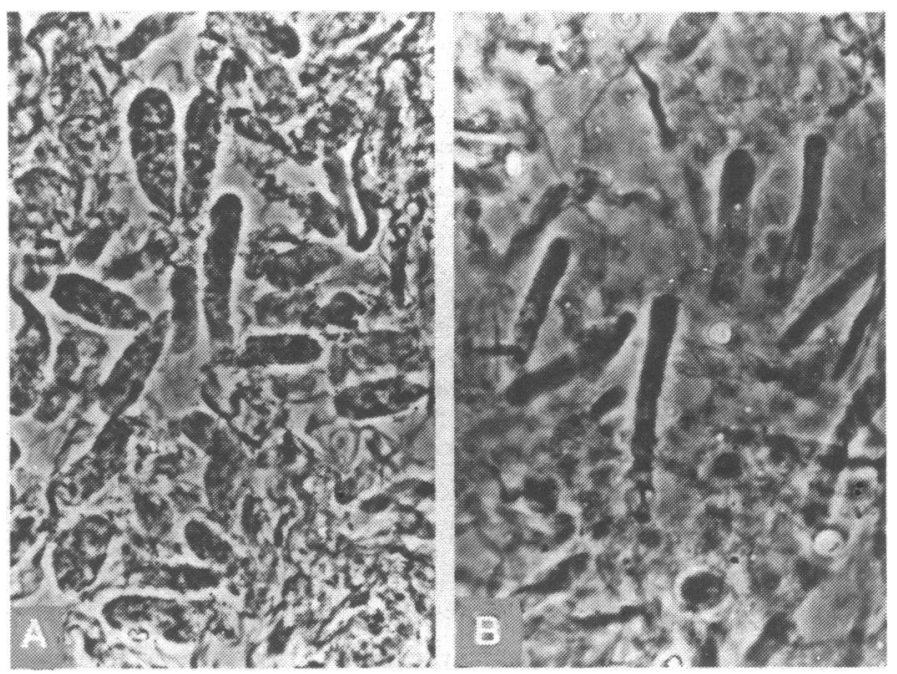

FIG. 1-Hyaline cylinders. (A) Two hours after an oral dose of $100 \mathrm{mg}$ of ethacrynic acid. (B) Four hours after an oral dose of $80 \mathrm{mg}$ of frusemide.

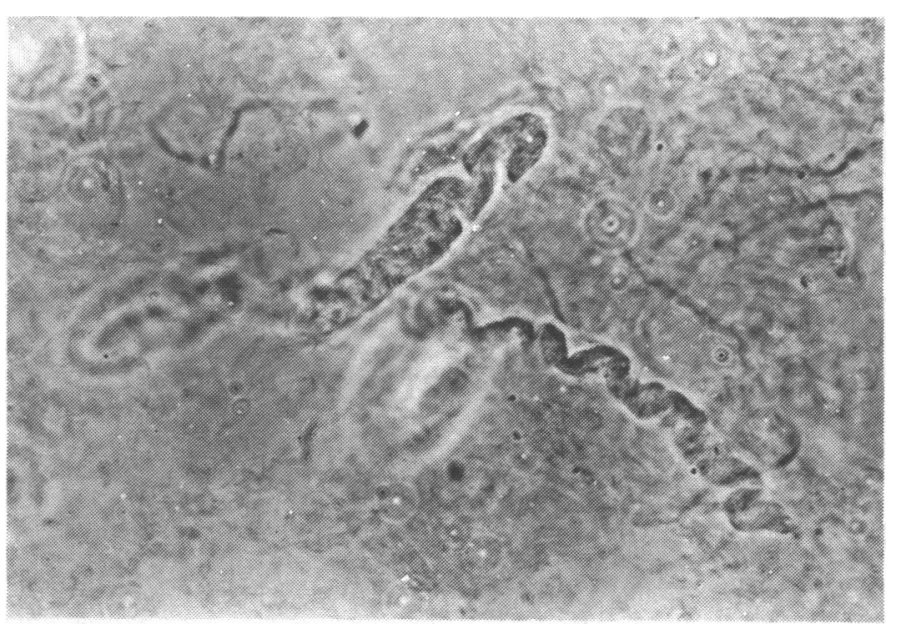

FIG. 2-Spiral structure of casts.

was no difference to be seen between these and hyaline casts passed by patients with kidney disease. Only very rarely was the excretion of casts accompanied by proteinuria, and when present this was invariably slight (opalescence to traces). The possibility cannot be entirely ruled out that these were cases of orthostatic albuminuria.

Quantity and Pattern of Cylindruria.-Quantitative estimations of the number of casts present in the urine of six subjects in each case showed, on the average, a maximum of $19,800 \pm$ 7,000 casts $/ \mathrm{ml}$ after a dose of $100 \mathrm{mg}$ of ethacrynic acid and of $3,700 \pm 1,800$ casts $/ \mathrm{ml}$ after a dose of $80 \mathrm{mg}$ of frusemide. The passage of casts started in the second hour and in almost all cases reached its maximum between three and six hours after the drug was taken. After six hours the number of casts excreted usually diminished considerably, and after 24 hours only isolated casts were detectable. As can be seen clearly from Fig. 3 the urinary output was already on the decline before the excretion 

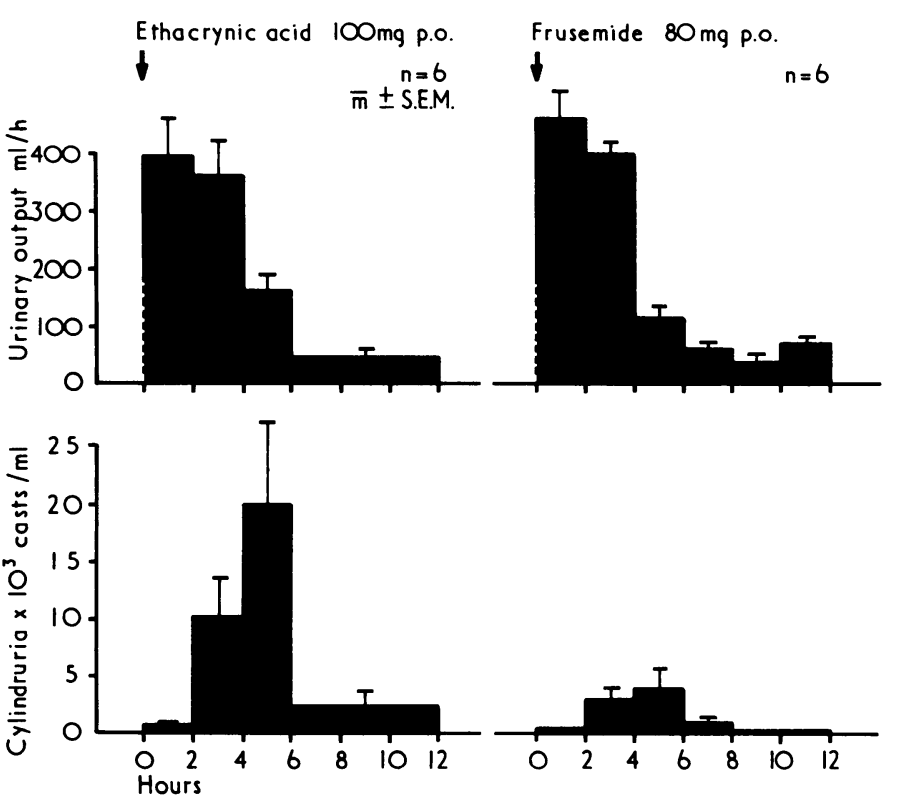

FIG. 3-Quantity and pattern of cylindruria in relation to urinary output.

of casts reached its peak. In the subjects given ethacrynic acid or frusemide over a period of several days cylindruria followed the same pattern each day as was seen after single doses. The number of casts excreted fluctuated slightly fom day to day, but massive cylindruria still persisted in some cases throughout the test period.

Comparisons with Water Diuresis, Osmotic Diuresis, and Diuresis Induced by Hydrochlorothiazide and Chlorthalidone.Under the conditions described above both the intake of a large volume of water and the infusion of mannitol resulted in an increase in urinary output comparable to that produced by ethacrynic acid and frusemide, but not in the excretion of casts. Nor were casts found in the urine of any of the subjects given hydrochlorothiazide or chlorthalidone. It should, however, be borne in mind that the maximum output of water and sodium induced by these two drugs was far less than that brought about by ethacrynic acid and frusemide.

Effect of Acidification and Alkalinization on the Excretion of Casts.-Studies undertaken to determine the influence of the $\mathrm{pH}$ of the urine on frusemide-induced cylindruria (ethacrynic acid was not tested) showed that casts were much more abundant and their excretion was continued longer after acidification $(\mathrm{pH}$ of urine $<5$ ) than after alkalinization ( $\mathrm{pH}$ of urine $>7$ ). Acidification alone was followed by the excretion of casts (about $500 / \mathrm{ml}$ of urine), and both hydrochlorothiazide and chlorthalidone augmented this cylindruria $(1,000-2,000 / \mathrm{ml})$.

Qualitative Determination of Composition of Casts.-As Table I indicates, all the casts examined by the indirect fluorescence method displayed a strong positive reaction to antiuromucoid. In contrast to the casts excreted after the administration of diuretics and after strenuous physical exertion, those

TABLE I-Qualitative Composition of Urinary Casts of Various Origins

\begin{tabular}{|c|c|c|c|c|}
\hline Antiserum & $\begin{array}{l}\text { Ethacrynic } \\
\text { Acid } \\
\text { Frusemide }\end{array}$ & $\begin{array}{l}\text { Hydrochloro- } \\
\text { thiazide } \\
\text { Chlorthali- } \\
\text { done after } \\
\text { Acidification }\end{array}$ & $\begin{array}{l}\text { Football } \\
\text { Players }\end{array}$ & $\begin{array}{l}\text { Kidney } \\
\text { Diseases }\end{array}$ \\
\hline 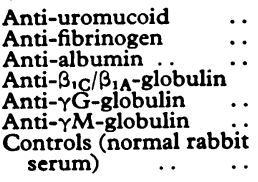 & $\begin{array}{l}(\stackrel{+}{(+)}) \\
= \\
= \\
=\end{array}$ & $\begin{array}{l} \pm \\
= \\
= \\
=\end{array}$ & $\begin{array}{l}(\stackrel{+}{(+)}) \\
= \\
= \\
-\end{array}$ & $\begin{array}{l}(+ \\
((+)) \\
(+) \\
(+) \\
(+) \\
(+) \\
(+)) \\
-\end{array}$ \\
\hline
\end{tabular}

$+\quad$ Fluorescence in all samples and practically all casts.

$(+)$ Fluorescence in all samples, but not all casts.

( $(+))$ Fluorescence in some samples and excreted by patients suffering from kidney diseases were found to contain albumin and various globulin fractions as well as uromucoid.

Quantitative Determination of Tamm-Horsfall Mucoprotein.The concentration and the hourly excretion of Tamm-Horsfall mucoprotein in the urine were first determined in six untreated healthy subjects. The average concentration was found to be $63.35 \pm 17 \cdot 15 \mu \mathrm{g} / \mathrm{ml}$, while the quantity excreted was $2.03 \pm 0.4$ $\mathrm{mg} /$ hour, which corresponds to the figure quoted by McKenzie et al. (1964). After medication with ethacrynic acid the TammHorsfall mucoprotein concentration declined to $3-4 \mu \mathrm{g} / \mathrm{ml}$ during the period of diuresis (0-4 hours) and increased again after four hours (Table II). The hourly excretion of Tamm-

TABLE II-Quantitative Estimation of Tamm-Horsfall Urinary Mucoprotein and Urinary Casts after Administration of Ethacrynic Acid (100 mg by mouth), $n=4$, Mean $\pm S$.E. of Mean

\begin{tabular}{|c|c|c|c|c|c|}
\hline \multicolumn{2}{|c|}{$\begin{array}{c}\text { Time of } \\
\text { Sampling after } \\
\begin{array}{c}\text { Medication } \\
\text { (hours) }\end{array}\end{array}$} & \multirow{2}{*}{$\begin{array}{c}\begin{array}{c}\text { Urine } \\
\text { Volume } \\
\text { (ml/hr) }\end{array} \\
465 \\
\pm 41 \cdot 3\end{array}$} & \multirow{2}{*}{$\begin{array}{c}\begin{array}{c}\text { Urinary Casts/ } \\
\text { ml }\end{array} \\
\begin{array}{c}644 \\
\pm 309\end{array}\end{array}$} & \multirow{2}{*}{$\begin{array}{c}\begin{array}{c}\text { Concentration } \\
\text { of T.-H. } \\
\text { Mucoprotein } \\
\text { ( } \mu_{\mathbf{g} / \mathrm{ml})} \\
4.70 \\
\pm 1.07\end{array}\end{array}$} & \multirow{2}{*}{$\begin{array}{c}\begin{array}{c}\text { Excretion Rate } \\
\text { of T.-H. } \\
\text { Mucoprotein } \\
\text { (ml./hr) }\end{array} \\
2.11 \\
\pm 0.43\end{array}$} \\
\hline $0-2$ & $\ldots$ & & & & \\
\hline $2-4$ & .. & $\begin{array}{c}333 \\
\pm 79 \cdot 3\end{array}$ & $\begin{array}{r}14,675 \\
\pm 2,183\end{array}$ & $\begin{array}{r}3.03 \\
\pm 0.83\end{array}$ & $\begin{array}{r}1.03 \\
\pm 0.28\end{array}$ \\
\hline $4-6$ & . & $\begin{array}{c}154 \\
\pm 31 \cdot 0\end{array}$ & $\begin{array}{r}20,956 \\
\pm 9,484\end{array}$ & $\begin{array}{r}10.20 \\
\pm 1.30\end{array}$ & $\begin{array}{r}1.62 \\
\pm 0.40\end{array}$ \\
\hline $6-12$ & $\ldots$ & $\begin{array}{r}32 \\
\pm 10.0\end{array}$ & $\begin{array}{r}3,238 \\
\pm 1,624\end{array}$ & $\begin{array}{r}25.93 \\
\pm 6.79\end{array}$ & $\begin{array}{r}0.91 \\
\pm 0.39\end{array}$ \\
\hline \multicolumn{4}{|c|}{ Control values $(n=6)$} & $\begin{array}{r}63.35 \\
\pm 17.15\end{array}$ & $\begin{array}{r}2.03 \\
\pm 0.40\end{array}$ \\
\hline
\end{tabular}

Horsfall mucoprotein remained within the foregoing normal range for the first two hours after medication-that is, during the period of maximum urinary output. Over the next 10 hours, however, it decreased markedly. While the excretion of urinary casts was at its maximum level, both the concentration and hourly excretion of Tamm-Horsfall mucoprotein in the urine were distinctly reduced.

\section{Discussion}

The cylindruria noted after the administration of ethacrynic acid and frusemide, and also of hydrochlorothiazide or chlorthalidone in subjects previously acidified with ammonium chloride, was not accompanied by any form of proteinuria demonstrable by means of the sulphosalicylic acid test. In contrast to the casts excreted by patients suffering from kidney diseases, these casts themselves also contained no proteins that could be precipitated by the usual methods. Immunofluorescence tests showed that they consisted of uromucoid, presumably identical with Tamm-Horsfall mucoprotein (Tamm and Horsfall, 1950), which is a physiological constituent of the urine normally present in solution. Under certain conditions, mucoprotein is precipitated and forms the matrix of all urinary casts, whether hyaline or granular (McQueen, 1962; McQueen and Sydney, 1966). It has been shown by immunofluorescence methods that in the human kidney this mucoprotein originates principally in the tubule cells of the ascending limb of the loop of Henle (McKenzie and McQueen, 1969).

The solubility of Tamm-Horsfall mucoprotein begins to diminish at $\mathrm{NaCl}$ concentrations of $0.07 \mathrm{M}$, and at concentrations of $0.58 \mathrm{M}$ precipitation is almost complete (Tamm and Horsfall, 1952). In addition, Tamm-Horsfall mucoprotein tends to form aggregates more readily when the $\mathrm{pH}$ of the urine decreases (McQueen and Engel, 1966). Diuretics and pretreatment with ammonium chloride can alter the intratubular milieu in such a way that Tamm-Horsfall mucoprotein is precipitated, whereupon cylinders become demonstrable in the sediment. Strenuous physical exertion leads to a decrease in urinary output; as a result, the concentration of Tamm- 
Horsfall mucoprotein increases (Patel, 1964), as does the concentration of electrolytes, and the $\mathrm{pH}$ of the urine declines, so that here, too, conditions prevail under which casts will form.

Since there was no demonstrable increase in the urinary excretion of Tamm-Horsfall mucoprotein after the administration of ethacrynic acid, the formation of casts cannot have been due to the presence of raised mucoprotein concentrations in the urine.

The frequently observed spiral structure of the casts can be explained by the fact that Tamm-Horsfall mucoprotein has a molecular weight of $7 \times 10^{8}$, and is about $5,600 \AA$ in length and $42 \AA$ in width (Tamm et al., 1955). Molecules of this description are known to have a tendency to form thread-like, spiral aggregates.

The excretion of casts also persisted throughout the course of several days' treatment with ethacrynic acid and frusemide; it is therefore not due to an initial flushing effect. Similar findings, incidentally, were reported 20 years ago during longterm therapy with ion-exchange resins (Friedman et al., 1951). The diuretics in question have all been in widespread use throughout the world for many years, and even during protracted treatment there has never been any indication that they might impair kidney function. It therefore seems to us that no pathological significance can be attached to the presence of casts in the urine after the administration of diuretics. On the other hand, our findings would seem to indicate that the diagnostic value of byaline casts is severely limited, unless special analytic methods (Rutecki et al., 1971) can be used to determine their exact composition.

\section{References}

Friedman, I. S., Zuckerman, S., and Cohen, T. D. (1951). American fournal of the Medical Sciences, 221, 672.

McKenzie, J. K., and McQueen, E. G. (1969). Fournal of Clinical Pathology, 22, 334 .

McKenzie, J. K., Patel, R., and McQueen, E. G. (1964). Australasian Annals of Medicine, 13, 32.

McQueen, E. G., (1962). Fournal of Clinical Pathology, 15, 367.

McQueen, E. G., and Engel, G. P. (1966). Fournal of Clinical Pathology, $19,392$.

McQueen, E. G., and Sydney, M. B. (1966). Lancet, 1, 397.

Patel, R. (1964). Australasian Annals of Medicine, 13, 170.

Rutecki, G. J., Goldsmith, C., and Schreiner, G. E. (1971). New England fournal of Medicine, 284, 1049.

Tamm, I., Bugher, J. C., and Horsfall, F. L. (1955). Fournal of Biological Chemistry, 212, 125.

Tamm, I., and Horsfall, F. L. (1950). Proceedings of the Society for Experimental Biology and Medicine, 74, 108.

Tamm, I., and Horsfall, F. L. (1952). Fournal of Experimental Medicine, 95, 71 .

\section{PRELIMINARY COMMUNICATION}

\section{Insulin Infusion Test of Gastric Acid Secretion}

\author{
D. C. CARTER, R. R. DOZOIS, J. R. KIRKPATRICK
}

British Medical fournal, 1972, 2, 202-205

\begin{abstract}
Summary
In view of the disadvantages of the standard insulin test for completeness of vagotomy a continuous insulin infusion test has been developed. Twenty-six tests were carried out on 12 healthy male volunteers. A dose of 0.04 unit of soluble insulin $/ \mathbf{k g} / \mathbf{h r}$ was found to produce the highest acid secretion with the least severity of symptoms of hypoglycaemia. The pattern of response was a plateau of acid secretion and of hypoglycaemia, and repeated studies in six subjects showed that the results were reproducible. Evaluation of this test after vagotomy and comparison with the standard insulin test are now required.
\end{abstract}

\section{Introduction}

The conventional insulin test to confirm completeness of gastric vagal denervation, although clinically valuable, remains potentially dangerous (Read and Doherty, 1970) and controversial

Department of Clinical Surgery, University of Edinburgh

D. C. CARTER, M.B., CH.B., F.R.C.S., Lecturer (Present address: P.O. Box 7072 , Department of Surgery, Mulago Hospital, Kampala, Uganda) R. R. DOZOIS, M.D., Research Fellow

J. R. KIRKPATRICK, GH.M., F.R.C.S., Senior Lecturer in its interpretation (Bank, Marks, and Louw, 1968; Gillespie, Elder, Gillespie, Kay, and Campbell, 1970).

$\mathrm{Re}$-evaluation of the test led us to consider the use of a continuous insulin infusion technique aimed at producing a steady-state acid secretion in response to a steady level of hypoglycaemia.

We report here our initial experience with a continuous insulin infusion test in a limited number of healthy adult subjects.

\section{Materials and Methods}

A total of 26 tests were carried out on 12 healthy male volunteers with no previous history of dyspepsia and ranging in age from 22 to 35 years.

After a 12-hour overnight fast a nasogastric tube was passed into the stomach to allow ready recovery of a trial $20-\mathrm{ml}$ instillate of water after discarding the fasting residue (Hassan and Hobsley, 1970). The tube was then connected to a vacuum pump for continuous gastric aspiration, which was interrupted every five minutes by air insufflation to ensure patency of the gastric tube. After two 15-minute samples of basal secretion had been collected the continuous insulin infusion was started. Soluble insulin (B.P.) was diluted in $154-\mathrm{mM} \mathrm{NaCl}$ to a total volume of $40 \mathrm{ml}$ and delivered intravenously by a constant slow injection pump for three hours. Five different doses of insulin ranging from 0.025 to $0.10 \mathrm{U} / \mathrm{kg}$ body weight/hr were investigated.

Venous blood for glucose determination was obtained, one sample being withdrawn before starting the infusion and 10 samples at 15-minute intervals after its initiation. A glucose oxidase method and an autoanalyser were used for this purpose.

Gastric aspiration was continued for three hours with the collection of 12 15-minute samples. Each sample was measured for volume $(\mathrm{ml})$, acid concentration $(\mathrm{mEq} / \mathrm{l}$.), and acid output (mEq). All titrations were made to $\mathrm{pH} 7.0$ with $0.1 \mathrm{~N} \mathrm{NaOH}$ in an automatic titrator (Radiometer, Copenhagen).

Throughout the test an E.C.G. tracing was taken every 15 minutes from standard lead II. 